\title{
PENINGKATAN KEMAMPUAN MEMBACA DAN IKLIM KOMPETISI DENGAN STRATEGI KAMUS BABUD
}

\author{
Nani Puspita Sari \\ SMA Negeri 2 Cepu, Kab. Blora, Jawa Tengah \\ Email: nanipuspita1@gmail.com
}

\begin{abstract}
Abstrak
Penelitian ini bertujuan untuk meningkatkan kemampuan membaca pemahaman dan iklim kompetisi murid menggunakan strategi Kamus Babud. Penelitian ini menggunakan metode Penelitian Tindakan Kelas. Metode ini dipilih untuk mendapatkan solusi terhadap masalah pengajaran yang ditemukan di kelas dalam mengajar di SMA kelas XI Bahasa. Data penelitian berupa data kuantitatif yang didapat dari tes, dan data kualitatif yang didapat dari kuesioner, pengamatan dan wawancara. Hasil dari penelitian ini menunjukkan bahwa Strategi Kamus Babud dapat meningkatkan kemampuan membaca dan iklim kompetisi di kelas XI Bahasa.
\end{abstract}

Kata kunci: kemampuan membaca, kompetisi, strategi, kamus babud.

\section{Pendahuluan}

Permendikbud No 69 tahun 2013 tentang Kerangka Dasar dan Struktur Kurikulum SMA menyebutkan bahwa kompetensi ideal Bahasa Inggris bagi peserta didik lulusan SMA adalah menguasai literature sebagai bekal di Perguruan Tinggi. Makna literature dalam Permen tersebut mencakup kemampuan berbahasa secara reseptif yaitu mendengar dan membaca, dan kemampuan produktif yaitu berbicara dan menulis. Empat ketrampilan berbahasa tersebut menjadi kompetensi dasar yang harus dikuasai murid. Pada aspek pengetahuan, tahapan kognisi yang minimal harus dikuasai adalah memahami, menerapkan, dan menganalisis. Pada aspek ketrampilan, kemampuan minimal adalah mengolah, menalar, dan menyaji. Sebelum mampu menganalisis dan menyaji, murid harus mampu mengidentifikasi, menentukan, memahami, dan membandingkan.

Sebagaimana halnya dengan ketrampilan mendengar dan ketrampilan berbicara, ketrampilan membaca dan menulis merupakan dua ketrampilan berbahasa yang saling mempengaruhi. Seseorang akan bisa fasih berbicara kalau dia banyak mendengar. Seseorang akan bisa menulis kalau dia banyak membaca. Kemampuan membaca pemahaman akan sangat mempengaruhi wawasan seseorang karena dengan banyak membaca dan memahami, seseorang akan mempunyai daya imajinasi tinggi, perbendaharaan kata yang luas, pengetahuan tata bahasa yang kompleks, pengetahuan budaya dan sosial politik yang beragam, dan mempunyai role model yang bervariasi untuk mengeksplorasi gagasan dan memecahkan masalah.

Kemampuan ideal seperti tersebut di atas belum terlihat dimiliki oleh murid kelas XI Bahasa SMA Negeri 2 Cepu tahun pelajaran 2016/2017. Intake murid untuk mata pelajaran Bahasa Inggris di kelas ini rendah. Murid yang masuk di SMA Negeri 2 Cepu kelas XI Bahasa adalah murid dengan rata-rata nilai Bahasa Inggris Ujian Nasional SMP adalah 5,04. 
Data penerimaan peserta didik baru tahun pelajaran 2015/2016 pada saat murid tersebut mendaftar di SMANegeri 2 terlihat bahwa murid yang berminat ke jurusan Bahasa hanya 4 murid, sedangkan lainnya berminat ke jurusan MIPA dan IPS. Analisa hasil tes IQ juga menunjukkan bahwa potensi jurusan murid ke program Bahasa berkisar antara 10 s.d $30 \%$, sedangkan hanya 5 murid yang berpotensi $60 \%$. Dari hasil wawancara, diketahui bahwa ratarata mereka mengatakan terpaksa bersedia masuk jurusan Bahasa agar bisa diterima di SMA Negeri, dan keterpaksaan ini mengakibatkan motivasi belajar yang rendah. Dari hasil observasi awal peneliti mendapati bahwa murid kelas XI Bahasa mempunyai penguasaan kosa kata yang rendah, ketrampilan membaca keras memprihatinkan, kompetisi antar murid nyaris tidak ada, dan budaya membacapun tidak terlihat. Kemampuan membaca keras yang tidak benar dari segi pengucapan kata (pronunciation) dan intonasi yang tidak tepat berimbas pada kemampuan murid dalam memahami bacaan. Ketidak lancaran murid dalam membaca ditambah penguasaan konsep tata bahasa yang lemah membuat pemahaman murid pada suatu teks menjadi salah.

Selain itu, kelas ini juga dihadapkan dengan masalah psikologis yang juga perlu ditangani. Iklim kompetisi antar murid dalam bidang akademik nyaris tidak ada. Kebanyakan murid kelas ini hanya sekedar melaksanakan apa yang seharusnya dilakukan anak sebaya mereka, yaitu sekolah untuk sekedar berangkat sekolah, hadir di kelas, mengikuti pelajaran, mengerjakan tugas, dan sekedar mengikuti ulangan. Semua dilakukan sekedarnya, mendapat nilai sekedar sesuai KKM walaupun harus melalui proses remidi beberapa kali.
Untuk mengatasi permasalahan tersebut, penulis melakukan penelitian untuk meningkatkan kemampuan membaca pemahaman dan iklim kompetisi murid menggunakan strategi Kamus Babud, singkatan dari Kompetisi Antar Murid Sekelas Bahasa dan Budaya. Peneliti melaksanakan kompetisi dalam hal membaca keras (reading aloud), menjawab pertanyaan bacaan (reading comprehension) secara tertulis, dan kombinasi antar keduanya dalam bentuk tanya jawab lisan (oral quiz).

Pada pelaksanaannya, 28 murid di kelas XI Bahasa dan Budaya dikelompokkan menjadi 5 kelompok, dan masing-masing kelompok memiliki ketua. Pemilihan ketua kelompok didasarkan pada rekam jejak murid selama mengikuti pembelajaran Bahasa Inggris di kelas sebelumnya, baik dari kompetensi kognitif, ketrampilan, sikap kepemimpinan, toleransi, dan kerjasama. Sifat kepemimpinan yang dimiliki ketua diharapkan mampu untuk mengkoordinir teman-teman dalam satu kelompok. Pemilihan pelaksanaan strategi pembelajaran dengan cara kerja kelompok mampu meningkatkan kepercayaan diri, tanggung jawab, dan kerjasama antar anggota. Setiap anggota kelompok mendapatkan tanggung jawab menyelesaikan tugas yang diberikan ketua kelompoknya. Dengan adanya pembagian maka tanggung jawab menyelesaikan tugas tersebut terasa ringan dan memungkinkan setiap murid mampu menyelesaikannya sehingga menumbuhkan kepercayaan diri. Pelaksanaan pembelajaran diformat dengan sistem kompetisi antar kelompok untuk menumbuhkan sikap kerjasama dan iklim kompetisi. Dengan demikian, setiap anggota kelompok harus bekerjasama untuk mendapatkan hasil terbaik bagi kelompoknya dalam rangka memenangkan persaingan antar kelompok. 
Pada pelaksanaan membaca keras, setiap kelompok diberi tugas membaca sebuah teks pendek yang sudah ditentukan. Guru memberi contoh cara membaca, kemudian para murid mempraktikkan di dalam kelompoknya, sehingga antar anggota kelompok saling mendengarkan dan saling mengoreksi. Tugas ketua kelompok adalah memilih salah satu anggota kelompok untuk membaca keras ke depan mewakili kelompoknya. Pelaksanaan membaca pemahaman dengan cara guru memberikan pertanyaan bacaan yang harus didiskusikan dalam kelompok. Setiap kelompok menulis jawaban pada secarik kertas dan menuliskan isi teks dengan kalimat sendiri kemudian dikumpulkan. Praktik tanya jawab dilaksanakan dalam bentuk kuis lisan. Rancangan strategi pembelajaran yang peneliti lakukan yaitu dengan mengintegrasikan antara ketrampilan mendengar, berbicara, membaca dan menulis.

\section{Kerangka Teori}

\section{Prinsip-Prinsip Belajar Bahasa}

Brown (2003) mengemukakan lima prinsip belajar bahasa yaitu: (1) menggunakan bahasa Inggris setiap hari sebagai alat komunikasi baik lisan maupun tulisan, (2) melibatkan bahasa inggris secara total, (3) selalu mencoba dan mencoba, (4) menciptakan suasana belajar diluar kelas, dan (5) menggunakan strategi belajar yang tepat dan terintegrasi semua ketrampilan berbahasa yaitu mendengar, berbicara, membaca, dan menulis. Oemar Hamalik (2001) menuliskan bahwa prinsip belajar itu meliputi: (1) dilakukan dengan sengaja, (2) direncanakan dengan struktur tertentu, (3) guru menciptakan pembelajaran buat murid, (4) memberikan hasil tertentu buat murid, (5) hasil yang dicapai dapat diukur, (6) sistem penilaian dilakukan secara berkesinambungan.
Dari teori-teori tersebut di atas, dapat dikatakan bahwa pembelajaran adalah mengubah tingkah laku. Guru bertindak sebagai pemberi stimulus dengan merencanakan dan menciptakan pembelajaran dengan struktur dan strategi tertentu secara terintegrasi, diberikan penilaian yang terus-menerus sehingga murid mendapatkan hasil yang terukur sehingga menciptakan kebiasaan yang dilakukan dalam keseharian.

Bredekamp, Copple \& Neuman (2006) mengatakan bahwa membaca keras adalah dasar dari pengembangan membaca literatur. Membaca keras menjadi aktivitas terpenting dari suksesnya kegiatan membaca. Mendengarkan orang lain membaca akan meningkatkan pemahaman dan ketrampilan. Murid akan belajar mengapresiasi bagaimana sebuah cerita ditulis dan akan terbiasa dengan aturanaturan penelitian (book conventions). Lebih jauh dikatakan bahwa membaca keras menunjukkan hubungan antara katakata yang tercetak dengan artinya.

Penelitian terbaru tentang membaca keras yang dirilis oleh Annenberg Foundation (2015) mengatakan bahwa membaca keras tidak hanya berguna bagi anakanak, namun juga sangat bermanfaat bagi remaja. Membaca keras bagi remaja akan merangsang imajinasi dan emosi mereka, memberikan contoh perilaku membaca yang baik, mengekspose kesusastraan mereka, memperkaya perbendaharaan kata dan pemahaman pola bahasa yang lebih kompleks, membuat teks yang sulit lebih mudah dipahami, memberi contoh bahwa jenis teks yang berbeda akan dibaca dengan cara yang berbeda pula, mendorong kemampuan membaca mandiri, menumbuhkan kepercayaan diri, dan memotivasi mereka untuk menikmati kegiatan membaca. 
Fountas \& Pinnel (1996) mengatakan bahwa dengan mendengarkan, murid dapat lebih mudah memahami tingkat bahasa yang lebih tinggi daripada mereka membaca sendiri. Membaca keras bisa membuat ide-ide yang kompleks lebih mudah dipahami dan bisa mengekspose kosa kata dan pola bahasa murid yang tidak digunakan dalam perbincangan keseharian. Hal ini akan membantu murid memahami struktur sebuah buku atau sebuah teks ketika mereka harus membaca mandiri.

Dari teori-teori di atas dapat disimpulkan bahwa kecakapan membaca keras akan mempengaruhi kecakapan memahami bacaan. Membaca pemahaman memerlukan suatu ketrampilan menemukan detail, menunjukkan pikiran pokok, menunjukkan urutan kegiatan, mencapai kata akhir, menarik kesimpulan, dan membuat evaluasi. Dengan memiliki kecakapan membaca juga akan mempengaruhi kepercayaan diri murid.

\section{Strategi Pembelajaran Kooperatif}

Dick and Carey (2005) mengatakan bahwa strategi pembelajaran adalah komponenkomponen dari suatu set materi termasuk aktivitas sebelum pembelajaran dan partisipasi peserta didik yang merupakan prosedur pembelajaran yang digunakan selanjutnya. Strategi pembelajaran merupakan cara-cara yang dipilih untuk menyampaikan metode pembelajaran dalam lingkungan pembelajaran tertentu (Gerlach \& Ely, 1990). Strategi pembelajaran yang digunakan untuk menyampaikan materi pengajaran hendaknya melibatkan partisipasi peserta didik agar tercapai pengajaran yang baik dan efektif. Strategi yang dapat digunakan adalah pembelajaran kooperatif. Wina Sanjaya (2006) mengatakan bahwa model pembelajaran kooperatif merupakan model pembelajaran dengan menggunakan sistem pengelompokan/tim kecil yaitu antara empat sampai enam orang yang heterogen. Untuk dapat mengaktifkan siswa dalam kelompok, dapat menggunakan metode quiz team. Dalvi (2006) menyatakan bahwa metode quiz team dapat menghidupkan suasana dan mengaktifkan murid untuk bertanya ataupun menjawab". Metode quiz team merupakan salah satu dari model pembelajaran kooperatif.

Dampak metode quiz team ini adalah dapat membentuk iklim persaingan kompetisi. Sebuah artikel pendidikan menyebutkan bahwa secara umum, pengertian persaingan (competition) adalah suatu proses sosial ketika ada dua pihak atau lebih saling berlomba dan berbuat sesuatu untuk mencapai kemenangan tertentu. Po Bronson (2013) mengatakan rasa dibanding-bandingkan, dorongan untuk tidak mengecewakan rekan satu timnya dimanifestasikan sebagai tekanan. Anak memang tidak bisa lepas dari tekanan, tapi sisi baiknya, tekanan itu ada pasang-surutnya. Pada sisi pasang, anak akan bertindak aktif dan bertanggung jawab untuk memberi yang terbaik bagi timnya. Tekanan yang memiliki titik akhir adalah elemen penting dalam kompetisi yang sehat. Dalam pertandingan yang terbatas, kita bersaing dan kemudian membiarkannya berlalu.

Dari uraian di atas dapat disimpulkan bahwa persaingan dapat digunakan untuk mendorong keaktifan dan tanggung jawab siswa untuk memenangkan kelompoknya. Namun demikian, persaingan haruslah dalam konteks persaingan yang memberikan hasil pada titik tertentu. Pengajaran yang mempunyai tekanan akan membuat murid terlatih dan terbiasa berkompetisi secara sehat.

Penelitian ini mengembangkan Model Pembelajaran Kooperatif menggunakan 
strategi quiz team yang juga diharapkan dapat mendukung iklim kompetisi yang positif. Pada pembelajaran, murid bekerja dalam kelompok heterogen. Setiap kelompok berlatih membuat dan menjawab pertanyaan, saling berkompetisi antar kelompok. Secara umum penelitian pengembangan Kamus Babud ini bertujuan untuk memberikan pengalaman belajar membaca yang menyenangkan dengan cara yang berbeda dari biasanya. Perbedaan ini menarik minat murid untuk mengikuti pembelajaran dengan aktif sehingga menumbuhkan rasa suka membaca dan membiasakan membaca. Secara khusus, penelitian ini bertujuan untuk meningkatkan kemampuan membaca pemahaman, dan meningkatkan iklim kompetisi antar murid kelas XI Bahasa dan Budaya.

\section{Metode Penelitian}

Metode penelitian yang digunakan adalah Penelitian Tindakan Kelas (PTK). PTK adalah penelitian yang mengambil setting sekolah sebagai tempat penelitian, dan mengambil permasalahan yang terjadi dalam kelas. Penelitian ini diadakan di SMA Negeri 2 Cepu, kelas XI Bahasa pada semester dua tahun pelajaran 2016/2017. Murid di kelas ini terdiri dari 28 orang dengan rincian 3 murid laki-laki dan 25 murid perempuan. Penelitian ini merupakan salah satu upaya peneliti dalam bentuk berbagai kegiatan yang dilakukan untuk memperbaiki dan meningkatkan mutu pembelajaran di kelas. Selama tindakan berlangsung, peneliti melakukan pengamatan perubahan perilaku murid dan faktor-faktor yang menyebabkan tindakan yang dilakukan tersebut sukses atau gagal. Pada penelitian ini, peneliti menggunakan prosedur penelitian PTK dari Kemmis and Taggart, dengan langkah-langkah sebagai berikut: Perencanaan, Pelaksanaan, Pengamatan, Refleksi. Hasil refleksi digunakan untuk merencanakan tindakan di siklus berikutnya. Langkah di siklus berikutnya kembali ke Perencanaan, Pelaksanaan, Pengamatan, dan Refleksi.

Pada refleksi awal, peneliti mengamati bahwa selama mengajar di kelas XI, kemampuan membaca murid sangat rendah. Nilai kognitif peserta didik dalam kompetensi dasar reading komprehensif jauh dari KKM yang ditetapkan. Iklim kompetisi di kelas ini juga nyaris tidak ada, ditandai dengan tidak adanya gairah belajar dan semangat belajar untuk menjadi yang terbaik.

Pada tahap perencanaan, peneliti mempersiapkan hal-hal sebagai berikut: (1) Mencari referensi mengenai teknik-teknik meningkatkan kemampuan membaca sekaligus meningkatkan partisipasi murid dan membiasakan berkompetisi secara sehat, (2) menyusun jadwal, (3) membuat instrumen berupa tes, kuesioner dan lembar interview, (4) menuliskan rencana pengajaran, membuat rubrik penilaian, dan (5) membuat lembar pengamatan lapangan. Pada tahap tindakan di siklus satu, peneliti menyampaikan tujuan pembelajaran dan strategi pembelajaran yang akan digunakan yaitu Kamus Babud. Kemudian peneliti memilih ketua kelompok dan mengajaknya terlibat dalam menentukan anggota kelompok. Kegiatan pembelajaran hari pertama siklus pertama diawali dengan pre-test, dilanjutkan dengan pemberian tugas pertama berupa membaca sebuah teks pendek dengan keras. Setiap kelompok diberi waktu untuk berlatih setelah peneliti memberi contoh terlebih dahulu. Setelah waktu yang ditentukan selesai, Ketua Kelompok menunjuk salah satu anggotanya untuk mempresentasikan membaca keras di depan.

Pertemuan berikutnya adalah latihan membaca komprehensif. Setiap kelompok 
membuat pertanyaan berdasarkan teks bacaan yang diberikan. Kemudian masingmasing kelompok saling melempar pertanyaan dan menjawab pertanyaan. Kegiatan ini diformat dalam bentuk kompetisi atau perlombaan baik secara tertulis maupun lisan. Kegiatan ini direncanakan dilakukan dalam dua kali pertemuan. Siklus satu diakhiri dengan post-test yang dikerjakan individual. Hasil di siklus satu diolah untuk dilihat kelebihan dan kekurangannya sebagai dasar bagi perencanaan di siklus berikutnya.

Pada tahap pengamatan, peneliti menggunakan tes, kuesioner dan wawancara untuk melihat efek penggunaan strategi Kamus Babud pada pembelajaran membaca. Data-data tersebut kemudian dianalisa secara deskriptif untuk menentukan indikator permasalahan yang belum meningkat agar bisa dipakai untuk pembenahan di siklus kedua. Berdasarkan refleksi di siklus pertama, maka siklus kedua diawali lagi dengan rencana, tindakan, pengamatan, dan refleksi. Apabila masih ditemukan kelemahan pada indikator tertentu, dilanjutkan ke tahap siklus berikutnya.

Peneliti mengumpulkan dua jenis data dalam penelitian ini, yaitu data kuantitatif dan kualitatif. Data kuantitatif diambil dalam bentuk nilai kognitif yang didapatkan dari pre-test dan post-test. Data tersebut dianalisis secara deskriptif dengan cara menghitung jumlah, menghitung ratarata (rerata), menghitung nilai persentase, dan membuat tabel.

Data kualitatif dikumpulkan menggunakan kuesioner, pengamatan, dan wawancara. Data kualitatif dalam penelitian ini dianalisis dengan analisis interaktif yaitu reduksi data, paparan data, dan penarikan kesimpulan. Untuk validitas data, peneliti menggunakan teknik triangulasi. Peneliti menerapkan bentuk triangulasi teknik pengumpulan data. Triangulasi teknik pengumpulan data ini untuk menguji kredibilitas data dengan cara mengecek data kepada sumber yang sama dengan teknik yang berbeda, yaitu melalui observasi dan wawancara.

\section{Hasil Penelitian dan Pembahasan}

Pertemuan pertama siklus 1 diawali dengan pre-test sebagai data awal kemampuan siswa. Pada tahap ini kegiatan yang dilakukan adalah modeling, drilling, dan presenting yang dikemas dalam bentuk kompetisi membaca antar kelompok. Pertemuan kedua diisi kegiatan reviewing, reading, dan constructing questions. Kegiatan pada pertemuan ketiga adalah reviewing, presenting, dan confirming. Pertemuan keempat diawali dengan mereview pelajaran sebelumnya. Kegiatan dilanjutkan dengan asking and answering questions, dan diakhiri dengan reflecting. Pertemuan kelima adalah post-test.

Hasil pada siklus pertama diketahui bahwa pada saat pre-test nilai tertinggi 74 dan dicapai oleh seorang murid saja. Pada posttest 1 , nilai tertinggi 90 dan dicapai oleh 3 orang murid. Rata-rata nilai yang semula 56,6 mengalami peningkatan menjadi 72,8 . Jumlah murid yang tuntas belajar dengan nilai Ketuntasan Minimal (KKM) sebesar 68 pada pre-test sebanyak 5 orang, sedangkan pada post-test 1 sebanyak 19 orang.

Hasil pengamatan membaca keras juga mengalami peningkatan. Dari aspek pronunciation yang semula tingkat kebenaran pengucapan hanya $10 \%$, meningkat menjadi $52 \%$. Aspek intonation mengalami peningkatan lebih besar yaitu $68.3 \%$ dari yang semula hanya $20 \%$.

Iklim kompetisi di kelas ini mulai tumbuh seiring dengan kepercayaan diri masing- 
masing murid yang mulai meningkat pula. Hal ini ditandai dengan semakin aktifnya setiap murid untuk memberi kontribusi nilai bagi kelompoknya dengan penuh tanggung jawab. Keaktifan murid naik dari yang semula $17 \%$ menjadi $53 \%$. Tanggung jawab pada tugas yang diberikan juga naik dari $17 \%$ menjadi $71 \%$. Namun, masih terlihat ada murid yang kelihatan belum menikmati suasana bekerja dan bersaing secara kelompok. Murid tersebut lebih asyik dengan kegiatannya sendiri daripada bergabung dengan teman kelompoknya. Ternyata murid ini pula yang mendapatkan hasil nilai terendah pada post-test. Pada saat menjadi perwakilan kelompok untuk membaca keras, murid tersebut juga kurang percaya diri.

Hasil refleksi pada siklus satu diketahui bahwa siswa tersebut kurang nyaman di kelompok tersebut. Anggota kelompok lain fokus pada perkembangan kompetensi mereka masing-masing dan kurang sabar dengan teman yang bertanya. Sebelum memasuki siklus kedua, peneliti menyampaikan pengantar kepada seluruh murid. Peneliti memasukkan pentingnya nilai-nilai karakter kerjasama dan peduli dalam kerja kelompok. Peneliti menguraikan bahwa seorang yang pintar itu ibarat mata air. Semakin banyak airnya dimanfaatkan, mata air tersebut tidak akan habis, bahkan akan semakin besar. Demikian pula orang pintar, dengan berbagi ilmu dan mengajari temannya, dia tidak akan menjadi bodoh, justru ilmunya akan semakin mantap dikuasai.
Pertemuan pada siklus dua diawali dengan evaluasi hasil post-test 1 . Kegiatan pada siklus dua diutamakan untuk mengatasi masalah yang ada di siklus pertama. Pada siklus dua, terdapat kegiatan oral quiz antar kelompok. Kegiatan kuis secara lisan ini dimaksudkan untuk lebih menumbuhkan iklim kompetisi secara terbuka. Mengadaptasi kompetisi system gugur, dua kelompok terbaik yang bertanding secara head to head.

Hasil kemampuan membaca pemahaman pada post-test 2 menunjukkan peningkatan. Tiga orang murid mendapat nilai tertinggi 95 , sedangkan 2 orang mendapatkan nilai 90 . Nilai 90 adalah nilai tertinggi pada posttest 1 . Murid yang mendapat nilai dibawah KKM hanya 3 orang dengan nilai 55 (dua orang), dan 60 (satu orang). Nilai terendah juga mengalami kenaikan dari post-test 1 . Rata-rata nilai yang di post-test 1 sebesar 72,8 menjadi 81,1 di post-test 2 .

Aspek kebenaran pronunciation pada posttest 2 mengalami peningkatan dari yang semula $52.2 \%$ menjadi $78.6 \%$. Aspek intonation juga mengalami peningkatan dari $68,2 \%$ menjadi $85.2 \%$ murid dengan intonasi yang benar.

Keaktifan dan tanggung jawab murid sesudah siklus 2 juga mengalami peningkatan. Murid yang aktif menjadi $96,4 \%$ pada saat pelaksanaan tindakan di siklus 2, sedangkan tanggung jawab meningkat menjadi $100 \%$.

Keseluruhan hasil siklus 1 dan siklus 2 dapat dilihat pada tabel berikut ini:

Tabel 1. Hasil Siklus 1 dan Siklus 2

\begin{tabular}{lllllll}
\hline Nilai & Pre-test & $\begin{array}{l}\text { Jumlah } \\
\text { Murid }\end{array}$ & Post-test 1 & $\begin{array}{l}\text { Jumlah } \\
\text { Murid }\end{array}$ & Post-test 2 & $\begin{array}{l}\text { Jumlah } \\
\text { murid }\end{array}$ \\
\hline Tertinggi 1 & 74 & 1 orang & 90 & 3 orang & 95 & 3 orang \\
Tertinggi 2 & 70 & 2 orang & 85 & 2 orang & 90 & 6 orang \\
\hline Terendah 1 & 30 & 2 orang & 40 & 1 orang & 55 & 1 orang \\
Terendah 2 & 35 & 5 orang & 50 & 6 orang & 60 & 2 orang \\
\hline
\end{tabular}




\begin{tabular}{lllllll}
\hline Nilai & Pre-test & $\begin{array}{l}\text { Jumlah } \\
\text { Murid }\end{array}$ & Post-test 1 & $\begin{array}{l}\text { Jumlah } \\
\text { Murid }\end{array}$ & Post-test 2 & $\begin{array}{l}\text { Jumlah } \\
\text { murid }\end{array}$ \\
\hline Lolos KKM & $>68$ & 5 orang & $>68$ & 19 orang & $>68$ & 25 orang \\
\hline Rata- rata & 56.6 & & 72.8 & & 81.1 & \\
\hline
\end{tabular}

Tabel 2. Hasil Pengamatan Membaca Keras

\begin{tabular}{lccc}
\hline \multicolumn{1}{c}{ Aspek } & Pre-test & Post-test 1 & Post-test 2 \\
\hline Pronunciation & $10 \%$ & $52.2 \%$ & $78.6 \%$ \\
\hline Intonation & $20 \%$ & $68.2 \%$ & $85.2 \%$ \\
\hline
\end{tabular}

Tabel 3. Hasil Pengamatan Iklim Kompetisi

\begin{tabular}{lccc}
\hline \multicolumn{1}{c}{ Aspek } & Sebelum & Sesudah Siklus 1 & Sesudah Siklus 2 \\
\hline Keaktifan & $17 \%$ & $53 \%$ & $96,4 \%$ \\
\hline Tanggung jawab & $17 \%$ & $71 \%$ & $100 \%$ \\
\hline
\end{tabular}

Dari hasil tindakan dengan strategi Kamus Babud selama dua siklus didapat peningkatan hasil ketrampilan membaca keras dan pemahaman yang menunjukkan keberhasilan penggunaan strategi ini. Iklim kompetisi yang selama ini tidak pernah terlihat di kelas Bahasa dan Budaya juga sudah mulai kelihatan. Para murid menunjukkan gairah belajar dan semangat mengeksplorasi diri untuk berkontribusi bagi kemenangan kelompoknya.

Penilaian membaca keras di sini bukan hal yang menjadi pokok penelitian, namun kemampuan membaca keras yang baik akan mempengaruhi kemampuan memahami bacaan. Murid yang mampu membaca keras dengan pronunciation dan intonation yang tepat, mudah memahami bacaan chunk by chunk dan tidak kata per kata. Selain itu, tata bahasa mereka juga akan semakin bagus, kosa kata semakin kaya, sehingga membantu dalam proses memahami. Hasil pengamatan membaca keras menunjukkan bahwa teori tersebut benar. Semakin bagus membaca keras, semakin bagus pula pemahaman bacaannya, terbukti dengan semakin baiknya hasil penilaian post-test para murid. Rata-rata nilai di post-test 1 sudah diatas KKM yaitu 72,8. Dengan
KKM 68, terdapat 7 orang dengan nilai terendah 30 dan 35 pada saat diadakan test sebelum tindakan. Setelah pelaksanaan siklus 1 , murid yang mendapat nilai dalam kisaran rendah masih 6 orang tetapi kisaran nilai yang mereka dapatkan naik menjadi 40 dan 50. Meskipun terjadi peningkatan hasil namun masih ada murid yang tidak tuntas belajar walaupun nilainya di atas 50 . Terdapat beberapa indikator yaitu mencapai kata akhir dan menarik kesimpulan yang masih banyak menjadi kendala para murid sehingga perlu dilakukan siklus 2 untuk mengatasi kendala tersebut.

Pada siklus 2, terdapat 3 murid yang masih mendapat nilai terendah yaitu 55 (satu orang), dan 60 (dua orang). Ketiga murid tersebut juga tidak tuntas belajar. Dari hasil wawancara dengan ketiga murid tersebut diketahui bahwa ketiganya mempunyai masalah pribadi yang mengganggu belajar mereka. Dua anak lainnya yang mendapatkan nilai 60 mengatakan bahwa nilai 60 itu adalah pencapaian tertinggi mereka selama belajar bahasa Inggris sejak SMP. Mereka bangga dengan hasil tersebut karena itulah pencapaian yang mereka dapatkan dengan belajar keras dan usaha sendiri. Secara umum, rata-rata hasil 
penilaian sudah jauh di atas KKM yaitu 81.1 (delapan puluh satu koma satu).

Peningkatan juga terjadi pada iklim kompetisi di kelas ini. Masing-masing kelompok berusaha menjadi yang terbaik. Semua ketua kelompok terlihat aktif menyemangati anggotanya supaya berusaha semaksimal mungkin. Rasa tanggung jawab juga ditunjukkan oleh masingmasing anggota dengan mengeksplorasi kemampuan sebaik mungkin. Mereka tidak segan-segan membuka kamus online digital untuk memastikan pronunciation dari sebuah kata. Seluruh murid tampak berusaha aktif agar mampu memberi kontribusi bagus pada kelompoknya. Keaktifan dan tanggung jawab meningkat prosentasenya.

Dari hasil refleksi di siklus kedua diketahui bahwa para murid di kelas ini suka dengan strategi yang digunakan peneliti karena mereka merasa bisa mengoptimalkan kemampuan diri. Mereka juga merasa dibutuhkan karena sekecil apapun kontribusi mereka akan sangat berpengaruh pada kelompoknya. Karena itu, mereka berusaha agar bisa memberikan kontribusi positif bagi kelompoknya. Tiga siswa yang belum tuntas belajar mengatakan bahwa mereka yakin bisa mengejar ketertinggalan mereka karena mereka sudah lebih percaya diri. Mereka tidak malu dan takut untuk bertanya kepada temannya yang lebih pintar. Apalagi, salah satu teman yang lebih pintar sudah menawarkan kegiatan belajar kelompok seminggu sekali sepulang sekolah.

\section{Kesimpulan dan Saran}

Berdasarkan Penelitian Tindakan Kelas yang dilakukan, terbukti bahwa Strategi 'Kamus Babud' dapat meningkatkan kemampuan membaca dan iklim kompetisi pada murid kelas XI Ilmu Bahasa dan
Budaya SMA Negeri 2 Cepu. Kemampuan membaca keras berpengaruh kepada kemampuan seseorang dalam memahami bacaan. Seseorang yang membaca dengan lancar, pengucapan benar, dan intonasi tepat, mampu memahami bacaan tersebut secara tepat dan komprehensif. Dia tidak terpengaruh dengan satu dua kata yang tidak dia ketahui maknanya. Alhasil, kemampuan membaca pemahamannya juga bagus.

Strategi Kamus Babud juga mendukung pembelajaran yang sesuai dengan Kurikulum 2013. Kurikulum 2013 menitikberatkan pembelajaran secara kolaboratif dalam menuju persaingan yang sehat. Strategi 'Kamus Babud' yang dirancang sebagai pembelajaran berbasis kelompok dengan sistem kompetisi antar kelompok terbukti berhasil memberikan solusi masalah bagi kelas XI IBB SMA Negeri 2 Cepu. Setiap murid di kelas tersebut mampu mengeksplorasi kemampuan diri tanpa melihat berapa skor yang dia capai, namun kontribusi apa yang sudah dia berikan bagi kelompoknya untuk mendapat pencapaian tertinggi. Kolaborasi dan kompetisi bisa berjalan seiring. Kedua proses tersebut harus dijalani dengan aktif, dan bertanggung jawab.

Berdasarkan temuan dari penelitian ini, peneliti memberikan saran kepada sesama guru bahasa untuk menggunakan strategi pembelajaran berbasis kelompok agar terjalin kolaborasi dan kompetisi yang seimbang. Selain itu, peneliti juga menyarankan agar para guru bahasa senantiasa meluangkan waktu untuk mengasah kemampuan membaca keras para muridnya agar kemampuan memahami bacaan juga semakin baik. Last but not least, peneliti juga menyarankan agar para guru terus berinovasi dalam pembelajaran agar semua potensi murid bisa dieksplorasi secara optimal. 


\section{Daftar Rujukan}

Annenberg (2015). Learner-Teacher Professional Development.. Diakses dari https://www.learner. org,teacherprofessional development., tanggal 30 Mei 2015.

Bredekamp, Copple C., \& Neuman S.B. (1998). Learning to read and write: developmentally Appropriate Practices for Young Children. Washington DC: NAEYC.

Bronson, Po., Merryman, Ashley. (2013). Top Dog: The Science of Winning and Losing. New York: Twelve Publisher.

Brown, H. Douglas. (2003). Language Assessment: Principles and Classroom Practice. White Plains, NY: Pearson Education.

Dalvi. (2006). Upaya Meningkatkan Keaktifan Belajar Murid dalam Pembelajaran Agama Menggunakan Metode Belajar Aktif Tipe Quiz Team. Jurnal Guru.

Dick, W., Carey, L. (2005). The systematic Design of Instruction. Glenview, IL: Scott Foresman, and Company.

Fountas, I.C and Pinnel, G.S. (1996). Guided reading: Good first teaching for all children. Portsmouth, NH: Heineman.

Gerlach, E. (1990). Teaching and Media A Systematic approach. New Jersey: Englewood Cliff Printice Hall, Inc.

Hamalik, O. (2001). Proses Belajar Mengajar. Jakarta : Bumi Aksara.

Sanjaya, W. (2006). Strategi Pembelajaran: Berorientasi Standar Proses Pendidikan. Jakarta : Kencana Prenada Media Group. 